\title{
Kesadaran Masyarakat Terhadap Kebersihan Lingkungan Sungai
}

Yulia Fitri Wijaya, Henni Muchtar

Program Studi Pendidikan Pancasila dan Kewarganegaraan

Universitas Negeri Padang

E-mail: yuliahgp@gmail.com

\section{ABSTRAK}

Penelitian kualitatif deskriptif ini bertujuan mendeskripsikan kondisi kebersihan lingkungan Sungai Batang Arau di Kecamatan Padang Selatan Kota Padang dan kesadaran masyarakat di sekitar terhadap kebersihan sungai. Informan penelitian terdiri dari Lurah Batang Arau, Kasi Trantibum dan Penanggulangan Bencana Kecamatan Padang Selatan, Kabid PSdK DLH Kota Padang, Kelompok Peduli Sungai Batang Arau dan masyarakat serta pengunjung di kawasan Sungai Batang Arau. Pengumpulan data penelitian dilakukan menggunakan teknik wawancara, observasi dan studi dokumentasi. Analisis hasil penelitian dilakukan melalui reduksi, penyajian, dan verifikasi data hingga kemudian dapat dilakukan penarikan kesimpulan. Hasil penelitian menunjukan kondisi Sungai Batang Arau yang tercemar oleh sampah-sampah makanan dan limbah rumah tangga serta bangkai kapal nelayan. Akibatnya muncul bau tidak sedap, berkembangnya bibit penyakit, rusaknya ekosistem dan pendangkalan aliran Sungai Batang Arau. Permasalahan ini terjadi karena rendahnya kesadaran masyarakat Kelurahan Batang Arau terhadap kebersihan sungai.

Kata Kunci: kesadaran masyarakat, kebersihan lingkungan, lingkungan hidup

\section{ABSTRACT}

This descriptive qualitative research aims to describe the condition of environmental cleanliness of the Batang Arau River in the Padang Selatan District of Padang City and the awareness of the surrounding community towards river cleanliness. The research informants consisted of Lurah Batang Arau, Kasi Trantibum Section and Disaster Management in South Padang District, Head of PSDK DLH Padang City, Batang Arau River Concern Group and the community and visitors in the Batang Arau area. Data was collected by interview techniques, observation and documentation studies. Analysis of the results of research is done through reduction, presentation, and verification of data so that conclusions can be drawn later. The results showed the condition of the Batang Arau River that was polluted by food and household wastes and the wrecks of fishing boats. As a result, the odor appears, the development of germs, damage to ecosystems and siltation of the Batang Arau river flow. This problem occurs because of the low awareness of the community of Batang Arau Village on river cleanliness.

Keywords : public awareness, environmental hygiene, environtment 


\section{PENDAHULUAN}

Dalam kehidupan manusia, sungai memiliki peranan penting. Bahkan hampir semua peradaban besar dalam sejarah umat manusia selalu berlangsung di tepi aliran sungai. Salah satunya Sungai Batang Arau yang mengaliri wilayah di Kota Padang. Kawasan di sekitar daerah aliran sungai ini merupakan salah satu kawasan pemukiman tertua, yang menjadi cikal bakal Kota Padang. Hingga saat ini, Sungai Batang Arau memiliki beberapa fungsi penting bagi masyarakat di sekitarnya. Pertama, sebagai salah satu pelabuhan strategis di Sumatera Barat, sebab di muara sungai inilah semua kapal penumpang dan kapal barang yang berasal dan menuju kepulauan Mentawai berlabuh. Kedua, sebagai salah satu destinasi wisata yang ramai dikunjungi di Kota Padang, baik oleh wisatawan domestik maupun mancanegara. Ketiga, sebagai sumber mata pencaharian bagi masyarakat nelayan yang mencari ikan di sepanjang aliran sungai. Dan terakhir, sebagai tempat mencari nafkah bagi para pedagang yang menjajakan makanan kepada para wisatawan.

Sebagai sungai yang memiliki nilai strategis bagi masyarakat, Batang Arau mengalami permasalahan sampah yang serius. Hal ini didasarkan pada temuan World Wild Fund for Nature (WWF) pada Desember 2018, bahwa 82 persen dari total 550 sungai di Indonesia dalam kondisi rusak akibat sampah dan rendahnya pemahaman atas manfaat sungai yang bersih. Pencemaran oleh sampah ini juga terjadi di Sungai Batang Arau, terutama pada aliran yang melintasi kelurahan Batang Arau kecamatan Padang Selatan Kota
Padang. Sampah-sampah yang mencemari kawasan sungai Batang Arau tersebut berasal dari bekas makanan yang di buang oleh para wisatawan dan pedagang, sampahsampah rumah tangga dan sisa-sisa bangkai kapal nelayan yang rusak dan karam. Apabila permasalahan sampah tersebut tidak diatasi dengan baik, maka akan timbul permasalahan kerusakan lingkungan di Sungai Batang Arau. Permasalahan lingkungan yang timbul akibat sampah di aliran Batang Arau antara lain kerusakan ekosistem sungai, pencemaran yang menyebabkan keracunan, hingga pendangkalan aliran sungai. Demi mencegah semakin parahnya pencemaran yang terjadi maka kesadaran masyarakat yang tinggal di daerah tersebut sangat dibutuhkan.

Beberapa penelitian terdahulu telah mengkaji persoalan pencemaran sungai, seperti Firmansyah (2015) yang membahas partisipasi masyarakat sekitar sungai dalam menjaga kebersihan lingkungan sungai. Hasil penelitian tersebut menyebutkan bahwa rendahnya partisipasi masyarakat dalam menjaga kebersihan sungai disebabkan kebiasaan yang menganggap membuang sampah ke sungai lebih praktis dan mudah. Selain itu, kurang memadainya sarana dan prasarana pembuangan sanpah menyebabkan masyarakat memilih membuang sampah ke sungai. Kemudian Purwanto (2018) melakukan penelitian terhadap perilaku sadar lingkungan pemukim bantaran sungai yang menyebutkan bahwa perilaku sadar lingkungan dipengaruhi oleh pendidikan dan pendapatan, keterbatasan biaya, ketersediaan sarana dan tempat juga 
menjadi kendala utama dalam mewujudkan perilaku sadar lingkungan. Perilaku sadar lingkungan masyarakat dipengaruhi oleh cara pandangnya terhadap lingkungan, sehingga untuk keberlanjutan lingkungan, masyarakat perlu menerapkan prinsip-prinsip etika lingkungan dalam kehidupan sehari-hari.

Penelitian ini membahas kesadaran masyarakat terhadap kebersihan lingkungan Sungai Batang Arau, dengan studi pada masyarakat di sekitar aliran sungai yang berada di Kelurahan Batang Arau Kecamatan Padang Selatan. Fokus penelitian adalah mendeskripsikan kondisi kebersihan Sungai Batang Arau dan kesadaran masyarakat terhadap kebersihan lingkungan sungai.

\section{METODE PENELITIAN}

Jenis penelitian ini adalah kualitatif-deskriptif yang bertujuan untuk mendeskripsikan kondisi kebersihan lingkungan Sungai Batang Arau dan kesadaran masyarakat di sekitar terhadap kebersihan sungai. Informan penelitian dipilih menggunakan teknik purposive sampling, terdiri dari Lurah Batang Arau, Kasi Trantibum dan Penanggulangan Bencana Kecamatan Padang Selatan, Kabid PSdK DLH Kota Padang, Kelompok Peduli Sungai Batang Arau dan masyarakat serta pengunjung di kawasan Sungai Batang Arau. Pengumpulan data penelitian dilakukan dengan menggunakan teknik wawancara, observasi dan studi dokumentasi. Analisis hasil penelitian dilakukan melalui reduksi, penyajian, dan verifikasi data hingga kemudian dapat dilakukan penarikan kesimpulan. Untuk menguji keabsahan data, digunakan teknik triangulasi data.

\section{HASIL DAN PEMBAHASAN}

Kondisi Kebersihan Lingkungan Sungai Batang Arau di Kelurahan Batang Arau Kecamatan Padang $\underline{\text { Selatan }}$

Sungai Batang Arau merupakan salah satu sungai yang mengalir di wilayah administrasi Kota Padang. Salah satu wilayah yang dilewati oleh aliran sungai Batang Arau adalah Keluruhan Batang Arau yang berada di Kecamatan Padang Selatan, Kota Padang. Di kelurahan tersebut, sungai Batang Arau tepat membagi wilayah kelurahan seperti yang nampak dalam gambar berikut:

\section{Gambar 1}

Peta Kelurahan Batang Arau, Kecamatan Padang Selatan, Kota Padang.

(Sumber : Kelurahan Batang Arau, 2019)

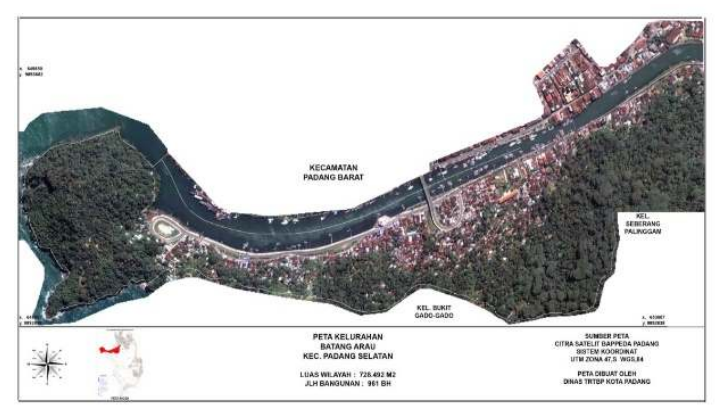

Dari temuan penelitian, di sepanjang daerah aliran sungai yang berada di Kelurahan Batang Arau telah terjadi pencemaran yang disebabkan oleh limbah dan sampah. Limbahlimbah dan sampah tersebut dapat berasal dari bangkai-bangkai kapal 
nelayan yang telah rusak, sampah bekas makanan dan limbah rumah tangga. Pencemaran lingkungan akibat sampah tersebut terjadi pada titik-titik yaitu di kawasan pedestrian. Dalam rangka mempermudah bagi pejalan kaki serta menambah nilai keindahan (estetika), pemerintah Kota Padang telah melakukan perbaikan jalan dan pembuatan trotoar di sepanjang pinggiran sungai Batang Arau. Hal ini sesuai dengan pendapat Rahman (2014) mengatakan bahwa kawasan pedestrian merupakan media di atas bumi yang memudahkan manusia dalam berjalan.

Kawasan pedestrian tersebut di lengkapi dengan tempat pembuangan sampah dan bank sampah beserta pengaturan waktu pembuangan sampah bagi warga masyarakat di sekitar daerah tersebut. Namun dalam temuan penelitian, masih banyak ditemukan tumpukan sampah yang dibuang secara sembarangan di sekitar pedestrian/trotoar. Sampah-sampah tersebut, terutama berasal dari buangan masyarakat sekitar maupun pengunjung yang datang ke lokasi tersebut. Hal ini dapat dilihat dalam gambar berikut:

Gambar 2.

Tumpukan sampah di badan jalan pada kawasan pedestrian tepian Sungai Batang Arau

\section{Sumber : dokumentasi penelitian, 2019}

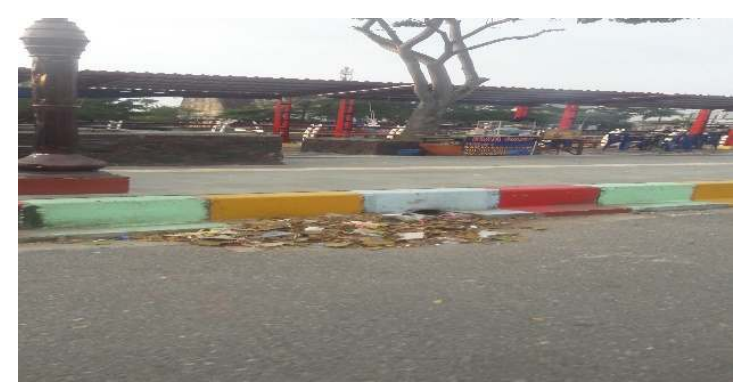

Kawasan selanjutnya yaitu kawasan pedagang. Pada beberapa titik di tepian sungai Batang Arau dimanfaatkan oleh para pedagang untuk menjajakan dagangannya kepada para pengunjung. Apalagi dengan bertambahnya jumlah pengunjung setelah renovasi di kawasan tersebut. Namun seperti diungkapkan oleh Kelompok Peduli Sungai Batang Arau, kebanyakan para pedagang tersebut masih belum memahami manajemen kebersihan lingkungan yang baik dan kaitannya dengan keuntungan ekonomis yang mereka dapatkan. Sehingga tak jarang ditemukan tumpukan sampah di sekitar lokasi para pedagang tersebut, seperti terlihat dalam gambar berikut:

Gambar 3

Sampah-sampah di sekitar lokasi jualan salah satu pedagang di tepi Sungai Batang Arau

\section{Sumber : dokumentasi penelitian, 2019}

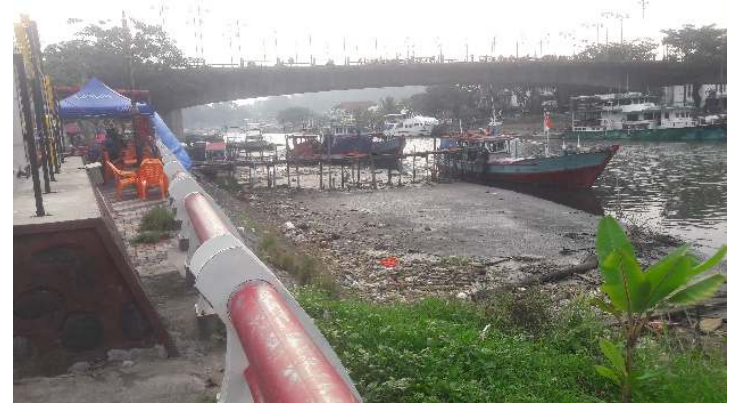

Selain di kawasan pedestrian dan pedagang yang berada di pinggiran sungai, juga banyak ditemukan sampah di permukaan maupun di dalam sungai. Aliran sungai dikotori dengan adanya bangkai kapal, sampah plastik, limbah rumah tangga dan lain-lain. Fenomena pencemaran Sungai Batang Arau oleh sampah dan bangkai kapal tersebut, dapat dilihat dalam gambargambar sebagai berikut: 


\section{Gambar 4}

Permukaan sungai Batang Arau yang dipenuhi oleh sampah dan bangkai perahu, (Sumber : dokumentasi penelitian, 2019)

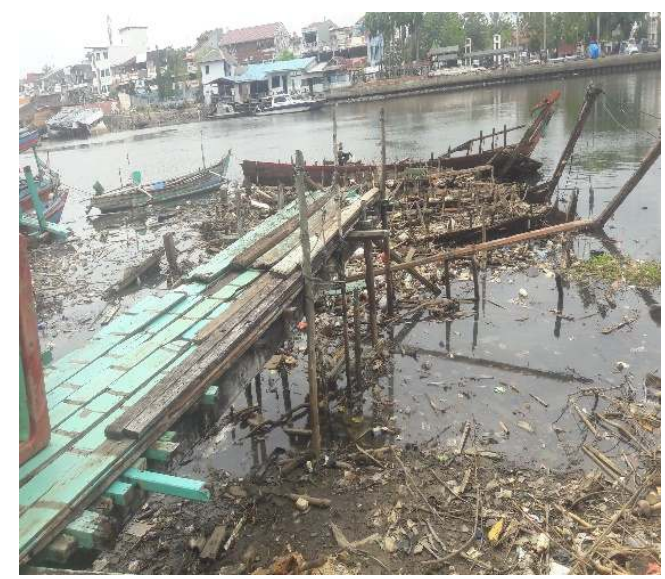

Gambar 5.

Permukaan sungai Batang Arau yang dipenuhi oleh sampah dan bangkai perahu

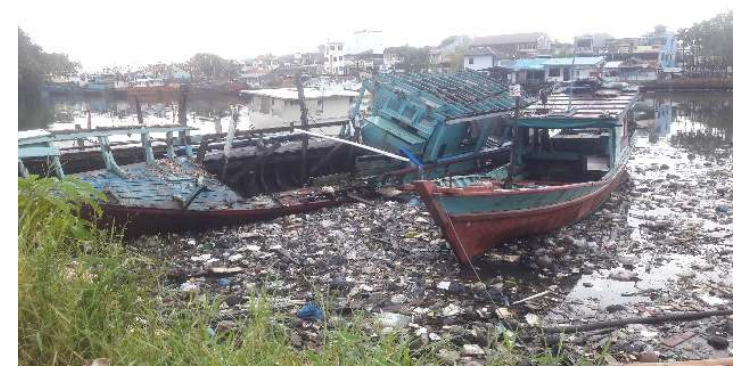

Pencemaran lingkungan sungai Batang Arau, selain merusak estetika atau keindahan lingkungan, juga menimbulkan dampak-dampak lainnya yang sejatinya merugikan masyarakat. Pertama, sampah yang telah menumpuk dan membusuk di permukaan sungai menimbulkan bau tidak sedap dan menjadi tempat pembiakan bibit-bibit penyakit. Kedua, limbah-limbah yang dibuang ke aliran sungai menyebabkan polusi yang membuat air berwarna kehitaman. Akibatnya ekosistem sungai rusak dan berdampak pada berkurangnya populasi ikan di sungai
Batang Arau. Hal ini berakibat pada berkurangnya pendapatan para nelayan yang mencangkap ikan di sungai tersebut. Selain itu, endapan sampah dan bangkai perahu menyebabkan terjadinya pendangkalan dan penyempitan aliran sungai. Pendangkalan dan penyempitan aliran sungai Batang Arau bisa menyebabkan terjadinya banjir di kawasan pemukiman di sekitarnya.

Kesadaran Masyarakat Terhadap Kebersihan Lingkungan Sungai Batang $\underline{\text { Arau }}$

Kesadaran lingkungan merupakan keadaan tergugahnya jiwa terhadap sesuatu yang terjadi di alam, khususnya lingkungan tempat ia berada (Amos Neolaka, 2008). Kesadaran lingkungan juga berarti kemampuan seseorang memahami apa permasalahan dan bagaimana yang seharusnya ada pada lingkungannya. Menurut Jamanti (2014) kesadaran lingkungan hidup dapat diukur dengan empat indikator, yang satu sama lain berkaitan sebagai sebuah tahapan, yakni pengetahuan, sikap, pola perilaku (tindakan).

Dalam temuan penelitian, beberapa masyarakat telah mengetahui akibat jika membuang sampah di aliran sungai. Sehingga mereka memilih untuk membuang sampah di tempat-tempat yang memang telah disediakan untuk itu. Akan tetapi, tidak semua masyarakat yang memahami hal tersebut dengan baik. Meski telah mendapat arahan dan penyuluhan dari pemerintah, tetap saja masih ada masyarakat yang tidak membuang sampah pada bank sampah yang telah disediakan dan lebih memilih membuang sampah di 
aliran sungai. Seharusnya dengan diberikannya penyuluhan tersebut, masyarakat paham dan tahu pentingnya menjaga kebersihan lingkungan sungai. Menurut Djaljhono dalam Karma (2012) bahwa ilmu pengetahuan tentang lingkungan dalam hal ini adalah lingkungan sungai mempunyai peranan esensial dalam penyadaran perlunya kebersihan lingkungan sungai, dengan adanya pendidikan mengenai kebersihan lingkungan sungai merupakan hal yang penting dalam membenuk pola pikir rasional sera bertanggungjawab dalam menjaga kebersihan lingkungan sungai.

Persoalan lain adalah masalah sikap. Penelitian ini menemukan bahwa masyarakat di sekitar sungai Batang Arau, sebagian setuju bahwa sampah dan pencemaran lingkungan sungai merugikan mereka. Pemerintah telah memasang papan larangan dan himbauan untuk tidak membuang sampah ke sungai Namun sebagian dari mereka cenderung tetap bersikap acuh tak acuh kepada ajakan untuk tidak membuang sampah ke sungai. Hal ini sesuai dengan pendapat Slameto dalam Yelina Henora (2006) sikap merupakan suatu respon atas segala sesuatu, yang biasanya berupa penerimaan atau penolakan. Sikap akan menghasilkan tindakan. Kesadaran masyarakat Kelurahan Batang Arau dalam menjaga kebersihan lingkungan sungai Batang Arau dapat dilihat dari perilaku atau tindakan sebagai kesadaran terhadap kebersihan lingkungan sungai. Bentuk tindakan yang dilakukan kelurahan dengan masyarakat yaitu membentuk Kelompok Peduli Sungai Batang Arau yang bertugas untuk membersihkan daerah aliran sungai. Namun dalam pelaksanaannya kelompok itu tidak berjalan dengan baik karena tidak semua anggota kelompok peduli sungai mengerjakan tugasnya dengan baik.

Dari uraian di atas, dapat dipahami bahwa kesadaran masyarakat terhadap kebersihan sungai Batang Arau, dilihat dari pengetahuan, sikap dan tindakan, masih belum baik dan merata. Sebab di antara masyarakat Batang Arau, ada yang telah memiliki pengetahuan dan bersikap yang menunjukan kesadaran lingkungan. Namun tidak sedikit yang tidak mau tahu dan tidak menggubris setiap upaya menjaga kebersihan sungai. Alhasil kebersihan lingkungan sungai masih jauh dari yang diharapkan.

\section{SIMPULAN}

Aliran sungai Batang Arau yang melintasi Kelurahan Batang Arau dicemari oleh sampah-sampah makanan dan limbah-limbah rumah tangga serta bangkai-bangkai kapal nelayan. Akibatnya muncul bau tidak sedap, berkembangnya bibit penyakit, rusaknya ekosistem dan pendangkalan aliran sungai Batang Arau. Permasalahan ini terjadi karena tidak meratanya kesadaran masyarakat Kelurahan Batang Arau terhadap kebersihan sungai. Maka para pembuatan kebijakan perlu memaksimalkan semua upaya dan menggunakan pendekatan dalam meningkatkan kesadaran masyarakat terhadap kebersihan sungai. Termasuk dengan menggunakan pendekatan hukum, dengan menegakkan semua aturan yang telah dibuat untuk pelestarian lingkungan.

DAFTAR PUSTAKA 
Neolaka, Amos. 2008. Kesadaran

Lingkungan. Jakarta: Rineka Cipta.

Firmansyah. 2015. Partisipasi Masyarakat Sekitar Sungai Kapuas Dalam Menjaga Kebersihan Lingkungan Dikelurahan Ilir Kota Kecamatan Kapuas Kabupaten Sanggau. Jurnal Ilmu Sosiatri. Diakses tanggal 22 Januari 2019. Purwanto, Nova. 2018. Perilaku Sadar Lingkungan Pemukim Bantaran Sungai Jelai, Kabupaten Sukamara. Jurnal Pembangunan Wilayah dan Kota Volume 14 Nomor 1. Diakses tanggal 22 Januari 2019. Jamanti, Retno. 2014. Pengaruh Berita Banjir Di oran Kaltim Terhadap Kesadaran Lingkungan Mayarakat Kelurahan Termindung Permai Samarinda. E Journal Ilmu Komunikasi. 2014, 2(1): 17 33.ISSN. diakses tanggal 22 Juli 2019.

Rahman, Nurhidayanti. 2014. Studi Kenyamanan Jalur Pedestrian Pada Kawasan Water Front (Studi Kasus : Jalan Penghibur Dan Jalan Somba Opu) 